\title{
Poglądy profesorów uniwersytetów europejskich na temat edukacii kobiet na poziomie wyższym. Analiza wybranych czasopism kobiecych Królestwa Polskiego z II połowy XIX i poczq̨tku XX wieku
}

Views of European University Professors on the Subject of Women's Higher Education: An Analysis of Women's Journals from the Polish Kingdom in the Second Half of the $19^{\text {th }}$ and the Beginning of the $20^{\text {th }}$ Centuries

StOWA KLUCZOWE edukacja dziewczqt, kobiety na uniwersytetach, opinie profesorów o studentkach, czasopisma kobiece, uniwersytet

KEYWORDS

education of girls, women at universities, professors' opinions about women students, women's magazines, university

Celem artykułu jest ukazanie poglaqdów pracowników wyższych uczelni europejskich oraz polskich uniwersytetów w Krakowie i Lwowie na temat możliwości kształcenia kobiet na poziomie wyższym. Analizie jakościowej poddano materiał źródłowy pochodzqcy z człerech czasopism kobiecych: „Bluszcza”, "Tygodnika Mód i Powieści”, „Świtu”, „Dobrej Gospodyni” oraz „Kroniki Rodzinnej” - pisma kierowanego do rodzin.

SPI Vol. 23, 2020/2

ISSN 2450-5358

e-ISSN 2450-5366 DOI: 10.12775/SPI.2020.2.001

Nadestano: 5.04 .2020 Zaakceptowano: 19.05.2020 
Ustalono, że w drugiej połowie XIX wieku na łamach czasopism niejednokrotnie zamieszczano artykuły zawierajace wskazówki i przestrogi dla młodych Polek, które zamierzały podjać studia wyższe na uniwersytetach zagranicznych. Uniwersytety w Szwajcarii i we Francji przyjmowały pierwsze studentki już w latach 60. XIX wieku, natomiast uniwersytety w Krakowie i Lwowie - dopiero trzydzieści lat później. Redakcje i publicyści czasopism informowali czytelniczki o warunkach studiowania, wymaganiach stawianych studentkom i napotykanych przez nie trudnościach. Przywoływano też opinie profesorów dotyczqce zdolności kobiet do podięcia kształcenia na poziomie wyższym. Poczq̨tkowo opinie te były dość zróżnicowane, jednak obserwacja coraz liczniejszej grupy studiujących dziewczq̨t, ich pilności i zaangażowania w pracę spowodowały, że znaczna część naukowców uznała, iż dziewczęta moga studiować z pożytkiem dla siebie i społeczeństwa.

\section{ABSTRACT}

The aim of the article is to present the views of employees of European and Polish universities (Krakow and Lviv) on the possibility of educating women at the tertiary level. The source material taken from four women's journals-Bluszcz, Tygodnik Mód i Powieści, Świt, and Dobra Gospodyni-as well as Kronika Rodzinna, a journal addressed to families, were subjected to qualitative analysis.

It was found that in the second half of the $19^{\text {th }}$ century, journals often published articles containing hints and warnings addressed to young Polish women who intended to study at universities abroad. Universities in Switzerland and France admitted their first female students as early as in the 1860s, while universities in Krakow and Lviv only did so 30 years later. Editors and journalists informed readers about the conditions of studying, the requirements for students, and the difficulties they could encounter. Professors' opinions about women's ability to undertake higher education were also cited. Initially, these opinions varied quite a lot, but the observation of the growing number of girls taking up studies and their diligence and commitment to the work meant that a significant proportion of scholars thought that girls could study for the benefit of themselves and society. 


\section{Wprowadzenie}

Jedną $\mathrm{z}$ istotnych kwestii, poruszanych w czasopismach kobiecych w II połowie XIX i pierwszych latach XX wieku, była sprawa dopuszczenia kobiet do kształcenia na wyższych uczelniach. W Stanach Zjednoczonych Ameryki Północnej pierwsza kobieta uzyskała tytuł doktora medycyny już w 1849 roku. Była to Angielka Elizabeth Blackwell, która zanim osiągnęła zamierzony cel, musiała przezwyciężyć liczne przeszkody. Wiele uniwersytetów negatywnie odpowiedziało na jej prośbę o przyjęcie w poczet studentów, a władze Geneva College w Nowym Jorku swoją decyzję w tej sprawie uzależniły od zgody studiujących mężczyzn. Studenci uznali, że to żart i przekornie poparli jej kandydaturę. W czasie studiów Blackwell niejednokrotnie spotykała się z nietolerancją i dyskryminacją, jednak tytuł doktora medycyny obroniła „z pierwszą lokatą” (Bąkowska 1900: 161-162). W Paryżu wolne słuchaczki uczęszczały na wykłady już od 1858 roku, zaś 10 lat później zdobyły pełne prawa studentek ${ }^{1}$. W Rosji w 1861 roku kilka dziewcząt podjęło studia na wydziale medycznym, ale wkrótce władze carskie wycofały dane im pozwolenie. W Zurychu przyjęto pierwsze studentki w 1864 roku, w Genewie i Bernie - w 1872, zaś w Neuchatel w 1878 roku (Wawrzykowska-Wierciochowa 1963: 219-222). Polskie uniwersytety w Krakowie i Lwowie przyjęły pierwsze studentki dopiero w połowie lat 90. XIX wieku, ale już znacznie wcześniej Polki wykazywały zainteresowanie wyjazdami na zagraniczne uczelnie.

Problematyka podejmowania przez kobiety studiów na uczelniach europejskich doczekała się wielu opracowań. Z okresu międzywojennego pochodzą publikacje Jana Hulewicza $(1936,1939)$. W ostatnich latach pisały na ten temat m.in.: Urszula Perkowska (1994), Mariola Kondracka (2000), Jadwiga Suchmiel (2004), Katarzyna Sikora (2007), Barbara Kalinowska-Witek (2011), Halina Wątróbska i Alicja Czyszak (2015), Jolanta Kolbuszewska (2017). Wydano też kilka opracowań zbiorowych, m.in. pod redakcją Barbary Jedynak (1990), Anny Żarnowskiej i Andrzeja Szwarca (1992, 1996, 2000), Krzysztofa Jakubiaka i Adama Winiarza (2000),

1 Wolne słuchaczki mogły uczęszczać na wykłady, ale nie mogły zdawać egzaminów; pełnymi prawami cieszyły się tylko słuchaczki zwyczajne. 
poświęconych edukacji kobiet (również na poziomie wyższym) i ich funkcjonowaniu w życiu społecznym. W wyżej wymienionych i innych publikacjach znajdują się jedynie wzmianki na temat poglądów profesorów wyższych uczelni, dotyczących możliwości kształcenia kobiet na poziomie uniwersyteckim. Niniejszy artykuł stanowi próbę wypełnienia istniejącej luki. Analizie poddano materiał źródłowy pochodzący z czterech czasopism kobiecych: „Bluszcza”, „Tygodnika Mód i Powieści”, „Świtu”, „Dobrej Gospodyni” oraz „Kroniki Rodzinnej” - pisma adresowanego do rodzin. Spośród nich trzy pojawiły się już w latach 60 . XIX wieku i ukazywały się aż do wybuchu I wojny światowej, „Świt” wydawano w latach 1884-1887, natomiast „Dobra Gospodyni” funkcjonowała na rynku wydawniczym od 1901 do 1915 roku (Zaleska 1938; Franke 1999).

W poddanych analizie czasopismach zamieszczano artykuły dotyczące życia codziennego kobiet, ważne miejsce zajmowała też problematyka edukacji dziewcząt. Wprawdzie zarówno „Bluszcz”, jak „Tygodnik Mód i Powieści” były czasopismami dość konserwatywnymi, sytuującymi kobietę przede wszystkim w rolach żony, matki i gospodyni domowego ogniska, jednak nie mogły pominąć milczeniem spraw, którymi interesowała się coraz większa grupa czytelniczek. Dlatego w tygodnikach zamieszczano informacje na temat studiów kobiet na zagranicznych uczelniach. Pisano o wymaganiach stawianych kandydatkom, warunkach studiowania, przeszkodach pojawiających się na drodze do zdobycia upragnionej wiedzy oraz trudnościach związanych $\mathrm{z}$ podjęciem pracy w wyuczonym zawodzie (Augusta 1886: 213; Gruszecki 1890: 321; Górski 1904: 481). Prezentowano też sylwetki kobiet, które ukończyły studia i podjęły pracę z korzyścią dla siebie i społeczeństwa. Pierwsze artykuły poświęcone tym kwestiom ukazały się w „Bluszczu” już w połowie lat 60. XIX wieku. Pozytywnie oceniano w nich postawy Elizabeth Blackwell i Elizabeth Garrett Anderson, które zdobywając wykształcenie wyższe, nie utraciły przy tym cech kobiecych (Lady Blackwell 1865: 152; Leja 1869: 379; Fritsche 1877a: 49-50). Zupełnie inaczej postąpiła Maria Walker, która zdaniem redaktorki „Bluszcza” ośmieszyła się,

2 W latach 1862-1871 czasopismo nosiło tytuł „Tygodnik Mód i Nowości”, zaś od 1913 roku zmieniono tytuł na „Nasz Dom”. Dla uproszczenia w tekście artykułu zastosowano nazwę, pod którą czasopismo ukazywało się najdłużej, tj. „Tygodnik Mód i Powieści”. 
zamieniając kobiece suknie na bardziej męski strój. Maria Ilnicka podkreślała, że nawet najbardziej wykształcona lekarka powinna zachować instynkt i kobiece poczucie skromności (Ilnicka 1867: 107). W następnych latach przypominano czytelniczkom postaci wybitnych lekarek (m.in. Teresy Ciszkiewiczowej, Anny Tomaszewicz, Zofii Sadowskiej), które stawiano za wzór, jak z pożytkiem dla siebie i innych ludzi wykorzystać posiadane zdolności i zdobyte wykształcenie wyższe (Kronika 1880: 199; Bąkowska 1900: 161; Prażmowska 1908: 490; Dr med. Zofia Sadowska 1914: 283).

\section{Poglądy pracowników wyższych uczelni z ostatnich dziesięcioleci XIX wieku na temat zdolności kobiet do podejmowania studiów wyższych}

W latach 70. XIX wieku pojawiły się w „Bluszczu” i „Tygodniku Mód i Powieści" pierwsze artykuły prezentujące opinie profesorów wyższych uczelni oraz przedstawicieli władz uniwersyteckich na temat potrzeby i możliwości edukacji kobiet na poziomie wyższym. „Kronika Rodzinna” zamieściła takie opinie po raz pierwszy niemal 30 lat później, gdy redakcja pisma uznała, że nauka jest potrzebna dziewczętom, które nie założą własnej rodziny, dla zapewnienia sobie niezależności materialnej (Silva rerum 1896a: 222-223; Silva rerum 1896b: 606-607). Zdania pracowników różnych uniwersytetów na temat zdolności intelektualnych kobiet były podzielone. Pozytywne opinie wygłaszali zwłaszcza profesorowie, którzy mieli już doświadczenie w pracy ze studentkami. To właśnie oni podkreślali, że znaczna część studentek zachowywała się bez zarzutu, pracowała z zapałem, rzetelnie wykonując swoje obowiązki, chociaż zdarzały się też wyjątki - czasami studia podejmowały młode kobiety, które z różnych przyczyn nie mogły lub nie chciały sprostać oczekiwaniom społeczności uniwersyteckiej (Studia kobiet 1872a: 129).

Chociaż w „Bluszczu”, „Tygodniku Mód i Powieści” i „Kronice Rodzinnej” niejednokrotnie podkreślano, że kobiety mają szczególną rolę do wypełnienia przede wszystkim w rodzinie, to jednocześnie uznawano, że powinny zdobyć odpowiednie wykształcenie. Te, które mają wystarczające zdolności, „sięgną po wiedzę wyższą [...], aby ubogaciwszy się jej światłem do życiowych zadań swoich wrócić 
i odpowiednio do przeznaczenia swego pełnić je potem" - pisano w „Bluszczu” (Studia kobiet 1872a: 129). Uspokajano, że nie należy się przy tym obawiać, iż kobieta studentka utraci swoją kobiecość lub że jej rodzina poniesie szkodę, gdyż „nauka formalna nigdy rodzinie tyle krzywdy nie wyrządzi, tyle matek dzieciom nie odbierze, domowych ognisk nie osamotni, ile ta pozioma niskość ducha, która z braku podniesienia umysłowego płynąc, tak często czyni kobietę istotą lekką i próżną" (Studia kobiet 1872a: 129). W czasopismach przeważnie zamieszczano przychylne kobietom wypowiedzi profesorów, jednocześnie przypominając, że na studia zagraniczne powinny wyjeżdżać jedynie te dziewczęta, które mają odpowiednie przygotowanie i wystarczające środki materialne oraz bardzo dobrze znają język wykładowy (Gruszecki 1890: 321).

W 1872 roku na łamach „Bluszcza” zaprezentowano poglądy profesorów pracujących na uniwersytecie w Zurychu. Na tamtejszym uniwersytecie w 1871 roku studiowało 17 kobiet, rok później było ich już 31 (w tym trzy Polki), większość studentek uczęszczała na zajęcia na wydziale medycznym (Studia kobiet 1872b: 137). W październiku 1871 roku dyplom doktora medycyny i chirurgii odebrała tam młoda Amerykanka z Bostonu. Profesor Eduard Meyer, obecny na uroczystości wręczenia dyplomu, stwierdził: „Pokazałaś Pani przez swój przykład, że kobiety zdolne są powołaniu lekarza się poświęcić, żadnej ujmy niewieściemu charakterowi nie czyniąc" (Studia kobiet 1872a: 130).

Wiktor Böhmert, inny z profesorów pracujących w Zurychu, chociaż nie był przeciwny przyjmowaniu kobiet na uniwersytet, zwrócił uwagę na słabe przygotowanie cudzoziemek do podjęcia nauki w szkole wyższej. Od kandydatów ze Szwajcarii wymagano świadectwa ukończenia gimnazjum, cudzoziemcy nie musieli spełniać tego warunku. Dotyczyło to również kobiet (Studia kobiet 1872b: 137). Böhmert sądził, że „studia medyczne wymagają przez ćwiczenia anatomiczne, przez zetknięcie się z chorobą i cierpieniem, takiej mocy charakteru, takiej moralnej wytrwałości a fizycznej siły, że tylko prawdziwie w powołaniu zamiłowane osobistości wytrwać mogą do końca. $Z$ tego też powodu nie można się nigdy obawiać zbyt wielkiej liczby kobiet, lekarskiemu zawodowi się oddających", gdyż te studentki, które podejmują studia bez odpowiedniego przygotowania lub zamiłowania, szybko z nich rezygnują (Studia kobiet 1872a: 129). 
Twierdził, że „wiedza nie może, nie powinna być przywilejem - przywilejem mężczyzny. [...] poważna pilność i szczere pragnienie nauki u większej liczb studiujących w Zurychu kobiet pozwala przypuszczać, że procent takich osobistości, które z nauki dobrze użytkować potrafią, nie będzie mniejszym u kobiet, jak u mężczyzn" (Studia kobiet 1872b: 137).

W Edynburgu na początku lat 70. XIX wieku studenci zażądali usunięcia kobiet z uczelni. Władze uniwersytetu, podobnie jak w Londynie, spełniły żądania studentów, chociaż profesorowie nie widzieli przeszkód do dalszego studiowania kobiet. Profesor medycyny Handyside ${ }^{3}$ twierdził: „Co do mnie, nie miałem jeszcze tak pilnych i z takim powodzeniem uzdatniających się studentów i gdyby moi koledzy oraz kolegium chirurgów nie odmówiło pozwolenia, byłbym szczęśliwy, mając ich jeszcze wokół siebie”, gdyż „nie ulega wątpliwości, że kobiety są wybornie uzdolnione, aby dojść do doskonałości $\mathrm{w}$ anatomii, chirurgii i farmacji i we wszelkim dziale powołania [...]. Przykład ich okazywał się szacownym dla młodzieży męskiej, czyniąc ją przez oddziaływanie pilniejszą, poważniejszą, więcej dbałą i regularną w obowiązkach" (Studia kobiet 1872b: 138).

Również z opinii zamieszczonych w „Tygodniku Mód i Powieści” wynikało, że szczególnie uzdolnione dziewczęta powinny mieć prawo do podejmowania kształcenia na poziomie wyższym. Pod koniec lat 70. w czasopiśmie opublikowano artykuł, w którym zapoznano czytelniczki z treścią odczytu wygłoszonego przez doktora Karola Benniego z Berlina. W wystąpieniu pt. „Kobieta-lekarz” doktor opowiadał się za przyznaniem dziewczętom prawa do podjęcia studiów, twierdząc, że kobiety posiadają odpowiednie zdolności i potrzebną wytrwałość do studiowania medycyny, a potem podjęcia pracy w wyuczonym zawodzie, więc nie należy „usuwać kobiety od wyższych nauk uniwersyteckich na jakich bądź wydziałach”, gdyż szczególnie „W zawodzie lekarskim kobiety wielkie usługi ludzkości oddać mogą, zwłaszcza jeśli się ograniczą do chorób kobiecych i dziecinnych. Ale

3 Niniejsza publikacja oparta jest na analizie materiału zawartego w czasopismach z drugiej połowy XIX i początku XX wieku. Niestety, czasami publicyści przytaczali jedynie nazwiska profesorów. Autorce opracowania nie zawsze udało się odnaleźć dodatkowe informacje na temat tych osób. Stąd przy nazwiskach uczonych czasami brakuje imion, informacji o dziedzinie wiedzy, którą się zajmowali lub też ich miejscu pracy. 
że nauka medycyny wymaga $\mathrm{z}$ ich strony zbyt wiele poświęceń, gdyż zmusza koniecznie do wyrzeczenia się kobiecości, największego jej wdzięku, a wraz z nią i do życia samodzielnego, przez odpowiednie wychowanie od dzieciństwa przygotować by się powinny" (Odczyty 1877: 115). Zdaniem Benniego, „Kobieta posiada tak zdolność, jak i wytrwałość potrzebną dla teoretycznego i praktycznego zajęcia się medycyną, i że działalność jej na tym polu jest niezbędną dla dobra ogółu kobiet, gdyż ochroni zdrowie wielu z nich i polepszy ich byt materialny, otwierając nową zupełnie gałąź pracy kobiecej” (Izabella 1877: 218). Uważał, że lekarki powinny się zajmować zwłaszcza akuszerią i chorobami dziecięcymi, ponieważ te działy wymagają szczególnej cierpliwości, której często brakuje mężczyznom.

$\mathrm{Na}$ łamach „Świtu”, jednego z bardziej postępowych czasopism kobiecych, informowano o stosunku profesorów francuskich do studentek. Profesorowie Sorbony w Paryżu byli początkowo niechętni słuchaczkom, zwłaszcza po samobójstwie pewnej Rosjanki popełnionym w trakcie egzaminów. Jednak dzięki pozytywnemu nastawieniu byłego dziekana Henriego Milne-Edwardsa, energii oraz zdolności i pracowitość studentek, Sorbona nie zamknęła swoich drzwi przed kobietami. Już w latach 80. XIX wieku większość prowadzących zajęcia traktowała obecność kobiet na wykładach jako zjawisko zupełnie naturalne. Tylko jeden z profesorów głośno wyrażał negatywny pogląd o studentkach. Dla publicystki powód jego stosunku do studentek był oczywisty: „Staruszkowi, który widocznie bardzo miał wrażliwe serce na niewieście wdzięki, przedstawiają się kobiety między uczącą się młodzieżą jako siła elektryczna, działająca przyciągająco na młodych pracowników [...]. Nie mogąc zaś zwiększyć pomiędzy niemi odległości, bo czasem przy robocie ich stoliki sąsiadują z sobą, przybiera on na siebie rolę eteranu elektrycznego i towarzyszy stale swym pupilkom. $Z$ tego wynika ambaras, który mu raz wyrwał z głębi serca westchnienie: $O$ ! te dziewwczyny! [...] żeby już raz zdały egzamin i poszły sobie do domu cerować pończochy! Mimo to pomaga tym dziewczynom z prawdziwie ojcowską dobrocią" (m...a 1885: 181).

Również w „Kronice Rodzinnej” publikowano poglądy naukowców dotyczące edukacji kobiet na poziomie wyższym. Cytowane opinie były umiarkowanie przychylne dla kobiet podejmujących studia. Zdaniem Ottona Pfleiderera, profesora protestanckiego fakultetu teologicznego, „bywają kobiety uzdolnione do studiów akademickich. 
Tym nie można odmówić prawa do uczęszczania na uniwersytet, przypuściwszy, że dopełniły wymaganych przez prawo warunków podobnie jak każdy student" (Silva rerum 1896b: 606). Uczony proponował jednak otworzyć dla studentek niewielki uniwersytet na prowincji. Profesor August von Esmarck z fakultetu medycznego stwierdził: „Do studiowania medycyny wewnętrznej i ginekologii nadają się może niektóre kobiety, ale chirurgię powinny by wyłącznie pozostawić mężczyznom" (Silva rerum 1896b: 607). Natomiast profesor Vincenz Czerny z Heidelbergu uważał, że kobiety powinny być dopuszczone do wszystkich fakultetów funkcjonujących w uniwersytecie, tj. medycznego, filozoficznego, prawnego i teologicznego (Silva rerum 1896b: 607).

Profesorowie większości uniwersytetów europejskich przeważnie nie widzieli przeszkód do wspólnego studiowania kobiet i mężczyzn. Twierdzili, że kobieta może sprostać obowiązkom związanym z podjęciem studiów. Zdarzały się jednak wyjątki. Jednym z nich był dr Gustaw Fritsche, który twierdził, że „przymioty nieodzownie potrzebne do skutecznego studiowania medycyny [...] w wyjątkowych tylko razach kobietom są właściwe, zatem nie należy zachęcać ich do obierania sobie drogi, na której prawie zawsze gorzki zawód je spotka" (Fritsche 1877b: 80). Podkreślał, że w medycynie kobiety nie mogą się wykazać takimi osiągnięciami, jak mężczyźni. Doceniał wprawdzie działalność Blackwell i Garrett Anderson, które zdobyły dyplomy doktorskie i z powodzeniem podjęły praktykę lekarską, ale twierdził, że należą one do wyjątków. Uważał, że nie ma potrzeby "tworzyć praw" umożliwiających kobietom nieograniczony dostęp do uniwersytetów. Dowodzi1: „Jeżeli kobieta z gruntu zmienić się potrafi i nabierze drogą udoskonalenia naturalnego owych przymiotów [...], to wtenczas wypadnie nam się zastanowić nad tym, czy korzyści stąd wynikłe są tak wielkie, iż zasługują na to, żeby kobietę odciągnąć od szczytnego powołania, do jakiego Bóg ją przeznaczył: początkowego wychowywania dzieci i wpajania pierwszych zasad moralności w przyszłych obywateli kraju" (Fritsche 1877b: 80).

Zdecydowanym przeciwnikiem podejmowania studiów wyższych przez kobiety był profesor Theodor von Bischoff, fizjolog i anatom uniwersytetu w Monachium w Niemczech. W rozprawie pt. Praktyka medyczna i studia medyczne dla kobiet dowodzil, że „kobieta niezdolną jest do wyższego wykształcenia, że robiłoby to zamieszanie w naturze, 
kuchni, rodzinie, że każda płeć ma właściwe sobie zajęcia i że kobiety nie mogą wypełniać tego, co wypełniają mężczyźni, a mężczyźni tego, co kobiety" (Literatura zagraniczna 1884: 153). Powoływał się przy tym na różnice w wielkości narządów u mężczyzn i kobiet. Twierdził, że „sama waga mózgu kobiecego świadczy już o słabszej sile umysłowej, tak jak wielkość i rozwój muskułów o sile fizycznej, z powodu więc takiej różnicy pod względem cielesnym i duchowym wynika, że płeć piękna niezdolną jest stanowczo do zajęć naukowych, szczególniej zaś do medycyny [...], ponieważ kobiety mają krótsze nogi, narząd głosowy i krtań nawet mniejszą, delikatniejszą i cieńszą skórę, dalej żołądek jej nawet mniejszy, więc tym samym wszystko to wpływa na zmniejszenie zdolności umysłowych" (Literatura zagraniczna 1884: 153).

Do przeciwników studiów kobiecych należała też dość duża grupa profesorów fakultetu filozoficznego na Uniwersytecie Berlińskim, wśród nich byli: Max Weber, Eduard Sachau i Heymann Steinthal. Ten ostatni dowodził: „Przypuśćmy, że pozyskalibyśmy odtąd dwa razy więcej uczonych, artystów i literatów, niż mieliśmy dotychczas w każdym pokoleniu, skutkiem właśnie pomocy rodzaju żeńskiego, i żeby między nimi znajdowali się Leibnitze, Rafaele i Mozarty płci żeńskiej - nie skorzystalibyśmy na tym tyle, ile straciłby przez to rodzaj ludzki - mianowicie swoją kobiecą połowę" (Silva rerum 1896b: 607). Wielu mężczyzn, podobnie jak część starszych kobiet, obawiało się, że ukończenie studiów pozbawi dziewczynę kobiecości i utrudni jej założenie rodziny.

\section{Poglady prezentowane na łamach czasopism w pierwszych latach XX wieku}

$\mathrm{Na}$ początku XX wieku, gdy wiele kobiet podejmowało, a następnie z powodzeniem kończyło studia wyższe, a pracownicy naukowi mieli już dość duże doświadczenie w pracy ze studentkami, jedno z bardziej poczytnych pism francuskich, dwutygodnik „Revue”, zwróciło się do profesorów i rektorów różnych uniwersytetów europejskich z zapytaniem o ich zdanie na temat wspólnego uczęszczania kobiet i mężczyzn na zajęcia uniwersyteckie oraz rezultatów osiąganych przez studentki podczas egzaminów, a później w pracy zawodowej. 
Wszyscy zapytani opowiedzieli się za dopuszczeniem kobiet do studiów uniwersyteckich razem z mężczyznami. Profesor historii starożytnej w Uniwersytecie Berlińskim Edward Meyer stwierdzit: „Kobiety uczęszczające na moje wykłady okazywały nie tylko zapał, ale i pojętność wielką... W stosunku z kolegami zachowywały się z taktem, bez zarzutu" (Świderska 1904: 13). Zdaniem Wilhelma Lexisa, profesora Uniwersytetu w Getyndze, kobiety na uniwersytetach niemieckich były poważniejsze i pracowitsze od mężczyzn. Do podobnych wniosków doszedł profesor chemii w Oxfordzie August Harcourt, twierdząc, że podczas wspólnej pracy ze studentami w laboratoriach kobiety zachowywały się właściwie, a ich obecność powodowała „poskromienie hałaśliwości i grubiaństwa młodzieży męskiej” (Świderska 1904: 13). Na korzyści wspólnej nauki kobiet i mężczyzn na poziomie wyższym zwrócił też uwagę Barrett Wendell, profesor języka i literatury angielskiej na paryskiej Sorbonie. Podkreślał, że kobiety „podczas uczęszczania na kursy wzbudzały szlachetną emulację i wyrabiały w otoczeniu swym pewną subtelność pojęć i sądów naukowych" (Świderska 1904: 13). Ponieważ w prasie pojawiały się głosy o nadmiernym przeciążeniu studentek pracą naukową, Gabriel Séailles, profesor filozofii w Sorbonie, zwrócił uwagę, że przecież kobiety pracują w fabrykach i warsztatach po $12-15$ godzin dziennie i nikt nie mówi o ich nadmiernym przeciążeniu obowiązkami. Również Luigi Credaro, profesor uniwersytetu w Rzymie, przyznał, że słuchaczki są pilne i wytrwałe, a w życiu późniejszym wykazują znacznie większe niż mężczyźni uzdolnienie profesorskie w szkołach ludowych i średnich. Korzystne zdanie o studiowaniu kobiet wyrazili też profesorowie szwajcarscy, którzy mieli najdłuższe doświadczenie w pracy ze studentkami (Świderska 1904: 13-14).

Maria Świderska podsumowując zebrane informacje podkreśliła, że „ogół profesorów zgadza się na przyznanie kobiecie pilności, wytrwałości, ambicji wysokiej, zapału i erudycji, obok delikatności i taktu w obejściu z kolegami [...]. Przeciwnie rzecz się ma co do zmysłu krytycznego, twórczości i ducha inicjatywy - tego bowiem braknie zazwyczaj kobietom, nawet uczonym, i skądinąd zdolnym [...], w ogóle kobieta uczona nie bywa geniuszem, lecz raczej zdolną, dzielną, wytrwałą, a nieraz pełną poświęcenia pracowniczką w dziedzinie wiedzy i zastosowania tejże w życiu praktycznym" (Świderska 1904: 13-14). Uspokoiła też czytelniczki, zwłaszcza matki dziewcząt 
udających się na uniwersytety, że studia „nie odbierają im wdzięku kobiecego ani cnót w życiu rodzinnym, do którego wchodzą jako kochające żony i matki troskliwe" (Świderska 1904: 14).

„Dobra Gospodyni” ukazała się na rynku wydawniczym w 1901 roku, gdy Polki mogły już studiować w galicyjskich uniwersytetach jako słuchaczki zwyczajne. Chociaż więc redakcja i publicyści nie zachęcali dziewcząt do podejmowania nauki na poziomie wyższym, ale raczej do uzyskania kwalifikacji zawodowych (np. w szkołach gospodarstwa wiejskiego), to również na łamach tego czasopisma poruszano czasami zagadnienia dotyczące wykształcenia uniwersyteckiego kobiet. W 1910 roku przybliżono czytelniczkom poglądy amerykańskiego profesora Johna Wheelera, badacza amerykańskich kolegiów. Twierdził on, że nauka nie zaszkodziła kobiecie, a obawy związane ze wspólną nauką młodzieży męskiej i żeńskiej okazały się płonne. Pisał: „Co zaś do studiów, to kobiety jeśli nie równie pilnie, to o wiele pilniej się uczą, bo nie odrywają ich od nauki tak, jak mężczyzn, sporty i inne rozrywki. Co zaś do badań na polu naukowym, to znów kobiety mniej działają, ograniczając swe dążenie do wiedzy raczej do rzeczy konkretnych, niż abstrakcyjnych" ( $Z$ życia kobiet 1910: 194). Wheeler zaobserwował, że podczas wspólnej ze studentkami pracy podniósł się poziom moralny studentów: „Studenci wobec kobiet starają się o utrzymanie czystości koło siebie i przyzwoite zachowanie. Popędy płciowe nie tylko nie są rozbudzane, ale przeciwnie, przez wspólne dociekania naukowe i przyrodnicze tłumione. Romantyzm blednie wobec formuł naukowych i cyfr matematycznych" ( $Z \dot{z} y c i a$ kobiet 1910: 194).

W 1914 roku „Tygodnik Mód i Powieści” przedstawił wyniki ankiety przeprowadzonej wśród naukowców uniwersytetów w Krakowie i Lwowie, dotyczącej studiów kobiet. W ankiecie pytano o to, „czy intelekt kobiecy wnosi do sfery naukowej odrębne pierwiastki”, czy w związku z przyjęciem studentek „poziom wykładów uniwersyteckich nie musiał ulec obniżeniu”, czy podczas egzaminów studentki „wykazują mniejszą lub większą samodzielność, niż u słuchaczów”, czy biorą udział w seminariach i przedkładają swoje prace, czy są wytrwałe w zdobywaniu wiedzy oraz ,jaką ze studiów i pracy kobiet na uniwersytecie prognozę można postawić dla nauki, a jaką dla życia praktycznego" (Studia uniwersyteckie 1914a: 1). Z wynikami 
zgromadzonych ankiet zapoznawano czytelniczki w kolejnych numerach pisma.

Profesorowie przeważnie nie dostrzegali różnic $\mathrm{w}$ rozwoju intelektualnym kobiet i mężczyzn. Jeśli jednak jakieś występowały, to zdaniem Odo Bujwida, profesora higieny na Uniwersytecie Jagiellońskim, wynikały one $\mathrm{z}$ różnic $\mathrm{w}$ wychowaniu dziewcząt i chłopców, natomiast „wychowanie niepraktyczne szkolne odbija się we wszystkich pracach dziewcząt i chłopców jednakowo" (Studia uniwersyteckie 1914f: 1). Na niedostateczny poziom przygotowania dziewcząt w zakresie szkoły średniej zwracał uwagę Emil Godlewski, profesor biologii i embriologii na Uniwersytecie Jagiellońskim, który pisał: „Miałem [...] wielokrotnie wrażenie, że wiele studentek, nie tylko nadzwyczajnych, ale i zwyczajnych, nie może dać sobie rady ze zrozumieniem wykładu" (Studia uniwersyteckie 1914a: 1). Natomiast Edward Porębowicz, profesor romanistyki na Uniwersytecie Lwowskim, stwierdzi1: „intelekt kobiecy [...] nie jest powołany do wnoszenia w życie duchowe pierwiastków nowych. Z natury swej recepcyjny, przetwórczy, mógłby odegrać rolę czynnika rozwojowego, gdyby na taką rolę podrzędną chciał się zgodzić” (Studia uniwersyteckie 1914e: 2).

Wszyscy profesorowie podkreślali, że nie zauważyli potrzeby obniżania poziomu wykładów z tego powodu, że brały w nich udział studentki. Michał Siedlecki, profesor zoologii Uniwersytetu Jagiellońskiego, stwierdził, że poziom wykładów nie obniżył się, gdyż podczas wykładów „cały balast nieprzygotowanych odpada i atmosfera się przez to oczyszcza" (Studia uniwersyteckie 1914b: 2). Józef Nusbaum-Hilarowicz, profesor biologii na Uniwersytecie Lwowskim, wyraził przekonanie, że „chyba żaden profesor uniwersytetu nie będzie swych wykładów w jakiejkolwiek mierze przystosowywał oficjalnie do słuchaczek" (Studia uniwersyteckie 1914c: 2). Ludwik Finkel, profesor historii na Uniwersytecie Lwowskim, podkreślił, że „wejście słuchaczek do sal wykładowych i pracowni akademickich nie przyniosło żadnej szkody nauce uniwersyteckiej. Poziom wykładów nie obniżył się, ani tok prac seminaryjnych nie zmienił się na niekorzyść wskutek udziału w nich kobiet" (Studia uniwersyteckie 1914d: 1). Porębowicz napisał: „Profesora uniwersytetu w odróżnieniu od nauczyciela szkół niższych w zasadzie nic nie zmusza, aby swój wykład dostrajał do poziomu tej średniej proporcjonalnej, jaką przedstawia mieszane audytorium. [...] Zresztą, słuchaczki pojmują nieraz szybciej, niż 
słuchacze, a podczas ćwiczeń praktycznych dają nieraz trafniejsze odpowiedzi” (Studia uniwersyteckie 1914e: 2). Natomiast Bujwid zaznaczył, że: „O ile idzie o poziom wykładów, to słuchacze obojej płci są jednakowo przygotowani, i naginać wykładów do poziomu słuchaczy nie potrzeba" (Studia uniwersyteckie 1914e: 1).

Profesorowie bardzo pozytywnie ocenili pilność i pracowitość kobiet, podkreślając jednocześnie ich mniejszą samodzielność w wykonywaniu prac i szybszą rezygnację w sytuacjach trudnych. Adam Wrzosek, profesor na wydziale medycznym Uniwersytetu Jagiellońskiego, zauważył, że studentki „odznaczają się na ogół większą pilnością, aniżeli studenci i regularniejszym od nich uczęszczaniem na ćwiczenia i wykłady, lecz tych tylko przedmiotów, z których trzeba składać egzaminy" (Studia uniwersyteckie 1914a: 2). Zdaniem Godlewskiego, „Kobiety pracują sumiennie, starannie, z większym nakładem pilności, niż mężczyźni, ale na ogół inicjatywę mają mniejszą. [...] Wartość prac wykonywanych przez kobiety nie jest mniejsza, niż prac mężczyzn. Na trwałą pracę naukową kobiet nie można jednak bardzo liczyć z powodu, że ogromna większość studentek wychodzi za mąż albo w czasie studiów, albo zaraz po ich ukończeniu. Wskutek tego $\mathrm{w}$ niejednym przypadku trud, włożony w przygotowanie kobiety do pracy samodzielnej naukowej, nie opłaca się tak wydatnie, jak u mężczyzn” (Studia uniwersyteckie 1914a: 1). Bujwid zaznaczy1: „Nie można np. stwierdzić, ażeby w pracach kobiet było mniej samodzielności. Jeśli weźmie się ona do pracy szczerze, utworzy sobie taki sam zapas samodzielności, jaki widzimy u chłopców" (Studia uniwersyteckie 1914e: 1). Natomiast profesor Porębowicz podzielił się następującą uwagą: „Zdolność opanowania przedmiotu sposobem pamięciowym w granicach danego szematu i wytrwała sumienność roboty, oto rysy znamienne pracy kobiecej wedle moich spostrzeżeń" (Studia uniwersyteckie 1914e: 2). Józef Kallenbach, profesor literatury polskiej na Uniwersytecie Lwowskim, zauważył u słuchaczek „większą zależność od skryptów wykładowych, niż u słuchaczów. Pilność i dokładność w wyuczeniu się skryptów jest nieraz zdumiewająca. Co do udziałów w ćwiczeniach seminaryjnych, da się zauważyć trudniejsze orientowanie się $\mathrm{w}$ sposobach pracy naukowej, większą potrzebę ciągłych wskazówek metodologicznych" (Studia uniwersyteckie 1914c: 1). Również Nusbaum-Hilarowicz zwrócił uwagę, że w laboratoriach studentki często wymagały więcej kierownictwa, 
zaś studenci wykazywali większą samodzielność, szukali bardziej oryginalnych rozwiązań (Studia uniwersyteckie 1914c: 2).

Żaden $\mathrm{z}$ ankietowanych profesorów nie negowal potrzeby zdobywania przez kobiety wykształcenia, badani podkreślali wartość rozwoju naukowego dla życia rodzinnego, czasami pracy zawodowej, natomiast w znacznie mniejszym stopniu dla rozwoju nauki. Zdaniem Wrzoska: „Ze studiów medycznych [...] mogą niewiasty odnieść niejedną korzyść. Wśród moich dawnych koleżanek znam kilka, które z powodzeniem praktykują jako lekarki-specjalistki w różnych działach medycyny. Te nawet niewiasty, które studiują medycynę, nie mając zamiaru praktykować w przyszłości, jak również te, które po wyjściu za mąż zaniechały zamiaru zajmowania się praktyką lekarską, mogą odnieść rzetelną korzyść ze studiów medycznych. Dzięki tym studiom, nabywają one gruntownych podstaw do umiejętnego wychowania fizycznego swoich dzieci" (Studia uniwersyteckie 1914a: 2). Profesor Kallenbach stwierdził: „Gdyby nawet rzesze kobiet, kończących odpowiednio studia uniwersyteckie, nie miały znaleźć stanowisk płatnych i zmuszone były - jak dotychczas bywa - przeważnie wychodzić za mąż, to przecież sprawa nie jest bynajmniej przegrana: owszem, im bardziej wykształcone będą matki przyszłych polskich pokoleń, tym większa będzie siła odporna społeczeństwa polskiego, tym wyższy poziom ogólny oświaty" (Studia uniwersyteckie 1914c: 1). Nusbaum-Hilarowicz dodał: „Kobiety naukowo wykształcone i przyzwyczajone do ścisłego i poważnego myślenia będą z większą pewnością rozumniejszymi matkami, lepszymi wychowawczyniami dzieci, a co najważniejsza, stosowniejszymi i więcej szanowanymi przez mężczyzn inteligentnych towarzyszkami ich życia, niż kobiety bez wyższego wykształcenia” (Studia uniwersyteckie 1914c: 2). Zdaniem Finkla, chociaż „otwarcie uniwersytetów dla kobiet nie spełniło dotychczas w całej pełni nadziei, które w pewnych kołach z nim związano, pomnożyło ono siły pracujące na polu naukowym, co uważać należy zawsze za korzystne, a przyczyniło się i ostatecznie przyczyniać się będzie do podniesienia poziomu życia rodzinnego i towarzyskiego" (Studia uniwersyteckie 1914d: 1-2). Bujwid dowodził: „kobieta-lekarz może zdziałać wiele [...]. Szczególnie na wsi praktyka lekarska dla kobiety przedstawia olbrzymie odłogiem leżące pole [...], stykając się bliżej z potrzebami ludzi, usunie niejedno zło, zwalczy niejeden przesąd, oszczędzi dużo zdrowia i życia, które 
pod wpływem komplikujących się warunków pracy są coraz częściej na szwank narażone" (Studia uniwersyteckie 1914e: 1-2). Najbardziej sceptycznie do sprawy wyższego wykształcenia kobiet podchodził Kazimierz Żorawski, profesor matematyki na Uniwersytecie Jagiellońskim. Uważał, że kobieta ma najważniejsze zadanie do spełnienia w rodzinie: „Matka jako wychowawczyni swoich dzieci musi mieć od kolebki bardzo ważny wpływ na ukształtowanie się ich charakterów i tam też leży główne jej zadanie moralne. Do odpowiedniego spełnienia tego zadania potrzeba gruntownego wykształcenia i kultury, ale wykształcenia, które powinno być odmienne od nauki, jaką posiąść musi mężczyzna do wykonywania pracy zawodowej" (Studia uniwersyteckie 1914b: 2).

Wielu profesorów sądziło, że kobiety, które nie zamierzają wykorzystywać zdobytej na uniwersytecie wiedzy do podjęcia pracy zawodowej, a jedynie dla własnego rozwoju i lepszego pełnienia obowiązków rodzinnych i społecznych, nie powinny podejmować studiów uniwersyteckich. Profesor Siedlecki przekonywał, że „dla bardzo wielu spośród kobiet, które na uniwersytecie szukają wykształcenia, byłoby lepiej, gdyby postarały się o nabycie zasad wiedzy zupełnie ogólnych, lecz ujętych w pewną całość, uniwersytet daje wykształcenie za specjalne i popycha ku specjalizacji. Wobec tego, że przeważna ilość kobiet nie kończy studiów lub nawet, ukończywszy je, nie korzysta z nich w całej pełni - byłoby lepiej, gdyby szukały rozwoju umysłu w takich instytucjach, które dają pewną całość wiedzy (np. Kursy imienia Baranieckiego), a nie w uniwersytecie. Do tej najwyższej instytucji powinny iść te jednostki, których od pracy naukowej życie nie oderwie; może by wówczas było mniej zawodów i zniechęcenia" (Studia uniwersyteckie 1914b: 2). Finkel opowiadał się za utworzeniem oddzielnych uniwersytetów dla kobiet, które byłyby „zupełnie tak samo urządzone i uposażone, z tymi samymi zadaniami i wymaganiami naukowymi, uniwersytety, w których obok docentów działały w równej mierze docentki. Nikt bowiem nie zaprzeczy, że istnieją pewne różnice intelektualne, jakkolwiek wielokrotnie mocno przeceniane, z którymi należałoby się liczyć nawet w akademickim traktowaniu nauki” (Studia uniwersyteckie 1914d: 1). Także Godlewski wysoko ocenił wartość wyższego wykształcenia kobiet, które będą wychowywać następne pokolenia i pracować z pożytkiem dla kraju. Twierdził jednak, że należy stworzyć dla nich oddzielne szkoły 
wyższe żeńskie, bardziej dostosowane do życia i obowiązków kobiety (Studia uniwersyteckie 1914a: 1-2). Porębowicz podsumował swoją wypowiedź słowami: „Uniwersytety [...] są szkołami wiedzy zespecjalizowanej, która wymaga oddania się na całą przyszłość. Podobnej abnegacji żądać od młodej abiryentki byłoby okrucieństwem; naukę jako cel jedyny życia uznają jedynie desperatki" (Studia uniwersyteckie 1914e: 1).

\section{Zakończenie}

Wypowiedzi profesorów dotyczące możliwości edukacyjnych kobiet były przeważnie przychylne studentkom. Przyczyniła się do tego niewątpliwie ogromna pracowitość i sumienność pierwszych dziewcząt podejmujących kształcenie na wyższych uczelniach. Zdawały sobie one sprawę, że muszą znacznie więcej pracować niż ich koledzy i dbać o dobrą opinię. W niemal wszystkich analizowanych czasopismach prezentowano wypowiedzi wybitnych przedstawicieli nauki, którzy pozytywnie oceniali pracę studentek i doceniali społeczną wartość edukacji kobiet na poziomie wyższym. Jedynie „Kronika Rodzinna" zamieszczała poglądy bardziej umiarkowane, asekuracyjne. Czasami w czasopismach kobiecych pojawiały się wypowiedzi mniej przychylne studentkom lub wręcz takie, w których negowano możliwości zdobycia przez kobiety wyższego wykształcenia ze względu na ich znacząco niższy niż u mężczyzn potencjał intelektualny. Poglądy takie prezentowano jednak tylko jako ciekawostkę lub zachętę do dyskusji na temat możliwości i potrzeby edukacji kobiet.

W artykułach publikowanych na początku XX wieku pytano o zdanie profesorów medycyny, nauk przyrodniczych, matematyki, historii i literatury, „tj. tych umiejętności, do których studiowania na uniwersytetach naszych kobieta została dopuszczoną; wypowiedzieli swój sąd o warunkach, właściwościach i wynikach pracy kobiecej w tej dziedzinie, oparty na długoletnim doświadczeniu"(Redakcja 1914: 1). Ich wypowiedzi jednoznacznie wskazywały, że kobieta może na równi z mężczyznami podejmować kształcenie na poziomie wyższym. „Uczy się pilnie, zdaje egzaminy, ogłasza rozprawy naukowe, osiąga stopnie najwyższe. I jako siła ukwalifikowana może stanąć do pracy zawodowej tak w medycynie, jak wyższym nauczycielstwie - na równi z mężczyzną" (Redakcja 1914: 1). Wprawdzie postrzegano 
kobietę jako nieco mniej samodzielną od mężczyzny, wskazywano na jej mniejszą inicjatywę, ale jednocześnie zauważono, że jest bardziej pracowita, dokładna i pilna. Zarzucano, że zbyt łatwo się zniechęca, ma zbyt wszechstronne i do tego zmienne zainteresowania. W nauce przeszkadzają jej ponadto zamążpójście i macierzyństwo (Redakcja 1914: 1).

Oczywiście nie wszystkie studentki osiągały zamierzony cel czasami na ukończenie studiów nie pozwalał im stan zdrowia, pogarszający się na skutek trudnych warunków materialnych i nadmiernej pracy, czasami niedostatek środków materialnych lub też przecenienie własnych zdolności. W pierwszych latach XX wieku, pomimo coraz większej liczby dziewcząt podejmujących studia, wciąż tylko niewielka ich część zdobywała wyższe wykształcenie i podejmowała pracę z pożytkiem dla siebie i innych (Trąmpczyński 1909: 177-178).

Na przeszkodzie w podjęciu pracy zawodowej stawała też znaczna konkurencja mężczyzn. Stąd kobiety-lekarki podejmowały przeważnie pracę na wsi, lecząc głównie kobiety i dzieci, natomiast mężczyźni obejmowali lepiej płatne posady. Podobna sytuacja miała miejsce w innych zawodach, w których kobiety stopniowo zdobywały wykształcenie równoważne mężczyznom.

\section{Bibliografia}

\section{Źródła}

Augusta (1886). Życie studentek paryzkich, „Bluszcz”, nr 27, s. 213-214.

[Bąkowska J.] Szczęsna (1900). Elżbieta Blackwell w 50-ta rocznicę doktoratu medycznego, „Bluszcz”, nr 21, s. 161-162.

Dr med. Zofia Sadowska (1914). „Bluszcz”, nr 26, s. 283.

Fritsche G. (1877a). Pani Garret Anderson i szkota medyczna dla kobiet w Londynie, „Bluszcz”, nr 7, s. 49-50.

Fritsche G. (1877b). Sprawozdanie z odczytu d-ra Karola Benni „O kobiecie lekarzu, ,Bluszcz”, nr 10, s. 79-80.

Górski S. (1904). Studentki w Galicji, „Bluszcz”, nr 41, s. 481.

Gruszecki A. (1890). Środki i siły, „Kronika Rodzinna”, nr 11, s. 321.

Ilnicka M. (1867). Miss Maria Walker. Doktor medycyny, „Bluszcz”, nr 26, s. $106-107$.

Izabella (1877). Gtos kobiet, „Tygodnik Mód i Powieści”, nr 19, s. 218-220.

Kronika dziatalności kobiecej (1880), „Bluszcz”, nr 25, s. 199. 
Lady Blackwell (1865), „Bluszcz”, nr 35, s. 152.

Leja E. (1869). Maria Walker, „Kronika Rodzinna”, nr 24, s. 379.

Literatura zagraniczna. Kobieta i wiedza (1884). „Tygodnik Mód i Powieści”, nr 20, s. 153-154.

[m...a] (1885). W Sorbonie, „Świt”, nr 63, s. 181.

Odczyty publiczne (1877). „Tygodnik Mód i Powieści”, nr 10, s. 115.

Prażmowska T. (1908). Przodownica, „Bluszcz”, nr 44, s. 490.

Redakcja (1914). Co powiedzieli w streszczeniu wybitni przedstawiciele wiedzy o studiach uniwersyteckich kobiet, „Tygodnik Mód i Powieści”, nr 11, s. 1.

Silva rerum (1896a). „Kronika Rodzinna”, nr 7, s. 222-223.

Silva rerum (1896b). „Kronika Rodzinna”, nr 19, s. 606-607.

Studia kobiet na uniwersytetach europejskich (1872a), „Bluszcz”, nr 17, s. 129-130.

Studia kobiet na uniwersytetach europejskich (1872b), „Bluszcz”, nr 18, s. 137-138.

Studia uniwersyteckie kobiet (1914a), „Tygodnik Mód i Powieści”, nr 2, s. 1-2.

Studia uniwersyteckie kobiet (1914b), „Tygodnik Mód i Powieści”, nr 3, s. 1-2.

Studia uniwersyteckie kobiet (1914c), „Tygodnik Mód i Powieści”, nr 4, s. 1-2.

Studia uniwersyteckie kobiet (1914d), ,Tygodnik Mód i Powieści”, nr 6, s. 1-2

Studia uniwersyteckie kobiet (1914e), „Tygodnik Mód i Powieści”, nr 8, s. 1-2.

Studia uniwersyteckie kobiet (1914f), ,"Tygodnik Mód i Powieści”, nr 9, s. 1-2.

[Świderska M.] M. Świd. (1904). Kilka stów o naukach uniwersyteckich dla kobiet, „Bluszcz”, nr 2, s. 13-14.

Trąmpczyński W. (1909). Wielkie wysitki-nikte rezultaty, „Dobra Gospodyni”, nr 23, s. 177-178.

W.N. (1876). Adeptki medycyny w Anglii, „Tygodnik Mód i Powieści”, nr 43, s. 510.

Wielkie wysitki - nikte rezultaty (1909), „Dobra Gospodyni”, nr 22, s. 169.

Z życia kobiet. Koedukacja w Ameryce (1910), „Dobra Gospodyni”, nr 25, s. 194.

\section{Opracowania}

Franke J. (1999). Polska prasa kobieca w latach 1820-1918. W kregu ofiary i poświęcenia, Warszawa: Wydawnictwo SBP.

Hulewicz J. (1936). Walka kobiet polskich o dostęp na uniwersytety, Warszawa: Zakł. Graf. „Drukarnia Polska”.

Hulewicz J. (1939). Sprawa wyższego wyksztatcenia kobiet w Polsce w w. XIX, Kraków: Polska Akademia Umiejętności.

Jakubiak K., Winiarz A. (red.). (2000). Wychowanie w rodzinie polskiej od schytku XVIII do potowy XX wieku, Bydgoszcz: Wydawnictwo Uczelniane WSP.

Jedynak B. (red.). (1990). Kobieta w kulturze i spoteczeństwie, t. 1, Lublin: Wydawnictwo UMCS. 
Kalinowska-Wiek B. (2011). W rodzinie i dla rodziny... Edukacja dzierwczat na przetomie XIX i XX wieku w wybranych czasopismach Królestwa Polskiego, Lublin: Wydawnictwo UMCS.

Kolbuszewska J. (2017). Polki na uniwersytetach - trudne początki, „Sensus Historiae", t. 26, nr 1, s. 35-53.

Kondracka M. (2000). Kobiety na uniwersytetach, [w:] A. Żarnowska, A. Szwarc (red.), Równe prawa i nierórwne szanse. Kobiety w Polsce międzywojennej, Warszawa: Wydawnictwo DiG, s. 271-284.

Perkowska U. (1994). Studentki Uniwersytetu Jagiellońskiego w latach 18941939. W stulecie immatrykulacji pierwszych studentek, Kraków: „Secesja”.

Sikora K. (2007). Pierwsze kobiety na Uniwersytecie Jagielloñskim, „Annales Academiae Paedagogicae Cracoviensis. Studia Politoligica III", t. 46, s. $248-268$.

Suchmiel J. (2004). Emancypacja naukowa kobiet w uniwersytetach w Krakowie i we Lwowie do roku 1939, „Prace Naukowe AJD. Pedagogika”, nr 13, s. $115-123$.

Wawrzykowska-Wierciochowa D. (1963). Od przadki do astronautki. Z dziejów kobiety polskiej, jej pracy i osiagnięé, Warszawa: Wydawnictwo Związkowe CRZZ.

Wątróbska H., Czyszak A. (2015). Teksty dziewwiętnastowieczne i problem ksztatcenia oraz wychowania kobiet w Polsce i Chorwacji, „Slawistyka”, t. 13 , s. $167-177$.

Zaleska Z. (1938). Czasopisma kobiece w Polsce (Materiaty do historii czasopism). Rok 1818-1937, Warszawa: Wyższa Szkoła Dziennikarska w Warszawie.

Żarnowska A., Szwarc A. (red.). (1992). Kobieta i edukacja na ziemiach polskich w XIX i XX wieku, cz. 1-2, Warszawa: Wydawnictwo UW.

Żarnowska A., Szwarc A. (red.). (1996). Kobieta i kultura. Kobiety wśród twórców kultury intelektualnej i artystycznej w dobie rozbiorów $i$ w niepodlegtym pañstwie polskim, Warszawa: Wydawnictwo DiG.

Żarnowska A., Szwarc A.. (red.). Kobieta i praca. Wiek XIX i XX, Warszawa: Wydawnictwo DiG.

\section{ADRES DO KORESPONDENCJI}

Dr hab. Barbara Kalinowska-Witek

Uniwersytet Marii Curie-Skłodowskiej w Lublinie

Wydział Pedagogiki i Psychologii

Instytut Pedagogiki

e-mail: barbara.kalinowska-witek@poczta.umcs.lublin.pl 